\title{
Pengaruh Suhu Pada Ekstrak Daun Cincau Hijau (Cyclea Barbata Miers) Sebagai Inhibitor Korosi Baja Pegas Daun
}

\author{
Intan Hani Saputri ${ }^{(1)^{*}}$, Ediman Ginting ${ }^{(1)}$, dan Dwi Asmi ${ }^{(1)}$ \\ ${ }^{(1)}$ Jurusan Fisika FMIPA Universitas Lampung \\ Jl.Prof. Dr. Sumantri Brojonegoro No. 1 Gedung Meneng Bandar Lampung 35144 \\ *E-mail:intanhanisaputri04@gmail.com
}

Diterima (16 Mei 2018), Direvisi (21 Mei 2018)

\begin{abstract}
This study aims to determine the extract of green cincau leaves (Cyclea Barbata Miers) as a corrosion inhibitor soaked in $3 \% \mathrm{NaCl}$ corrosive medium. To determine the effect of concentration and temperature to connect steel, the average inhibitor is $0,2,4$, and $6 \%$ and each temperature is $40^{\circ} \mathrm{C}$ and $80^{\circ} \mathrm{C}$. To find out the measurements done by the method, save weight. Corrosion rate at immersion temperature is $40^{\circ} \mathrm{C}$ lower than speed at $80^{\circ} \mathrm{C}$ immersion temperature. To find out the phase formed and the structure of the sample in XRD and SEM-EDS characterization. The X-Ray Diffraction (XRD) characterization results show that the phase formed is pure Fe. XRD results showed that the lowest Fe peaks were formed on samples without inhibitors at $80^{\circ} \mathrm{C}$. The results of SEM characterization of PGDaun-80-6 steel also showed that it looked more corroded, and the PGDaun-40-2 sample looked slightly corroded. This result is reinforced by the percentage of corrosion products shown in the EDS results.
\end{abstract}

Keywords: Corrosion inhibitors, green cincau leaves, leaf spring steel, $\mathrm{NaCl}$.

\begin{abstract}
Abstrak.Penelitian ini bertujuan untuk mengetahui efektivitas ekstrak daun cincau (Cyclea Barbata Miers) sebagai inhibitor korosi direndam dalam medium korosif $\mathrm{NaCl} 3 \%$. Untuk mengetahui pengaruh konsentrasi inhibitor dan suhu perendaman terhadap korosi baja dilakukan dengan variasi konsentrasi inhibitor yaitu 0,2 , 4, dan $6 \%$ dan variasi suhu yaitu $40^{\circ} \mathrm{C}$ dan $80^{\circ} \mathrm{C}$. Untuk mengetahui laju korosi dilakukan dengan metode kehilangan berat.Laju korosi pada suhu perendaman $40^{\circ} \mathrm{C}$ lebih rendah daripada laju korosi pada suhu perendaman $80^{\circ} \mathrm{C}$.Untuk mengetahui fasa yang terbentuk dan struktur mikro sampel di karakterisasi XRD dan SEM-EDS. Hasil karakterisasi X-Ray Diffraction (XRD) memperlihatkan bahwa fasa yang terbentuk adalah Fe murni. Hasil XRD menunjukkan bahwa terbentuk puncak Fe terendah yaitu pada sampel tanpa inhibitor pada suhu $80^{\circ} \mathrm{C}$. Hasil karakterisasi SEM baja PGDaun-80-6juga menunjukkan bahwa terlihat lebih terkorosi, dan pada sampel PGDaun-40-2terlihat sedikit terkorosi.Hasil ini diperkuat dengan persentase produk korosi yang ditunjukkan pada hasil EDS.
\end{abstract}

Kata kunci:Inhibitor korosi, daun cincau hijau, baja pegas daun, $\mathrm{NaCl}$.

\section{PENDAHULUAN}

Inhibitor korosi didefinisikan sebagai suatu zat yang apabila ditambahkan kedalam lingkungan korosif akan menurunkan serangan korosi dari lingkungan tersebut pada logam. Umumnya inhibitor korosi berasal dari senyawa organik dan anorganik yang mengandung gugus yang memiliki pasangan elektron bebas. Secara umum, kandungan daun cincau hijau (Cyclea Barbata Miers)adalah karbohidrat, lemak, protein dan senyawasenyawa lainnya seperti polifenol, flavonoid serta pada mineral-mineral seperti kalsium, fosfor, vitamin A, dan vitamin B. Berdasarkan penelitian yang dilakukan oleh menunjukkan bahwa daun cincau hijau (Cyclea Barbata Miers) memiliki senyawa metabolit sekunder seperti flavonoid, alkaloid, saponin, tanin, dan steroid. 
Berdasarkan penelitian yang dilakukan sebelumnya menunjukkan bahwa daun cincau hijau (Cyclea Barbata Miers) memiliki senyawa metabolit sekunder seperti flavonoid, alkaloid, saponin, tanin, dan steroid.Tanin merupakan senyawa yang dapat larut dalam air, gliserol, alkohol, dan hidro alkohol, tetapi tidak dapat larut dalam petroleum eter, benzeene, daneter. Senyawa tanin terdiri dari senyawa fenolik yang susah dipisahkan dan sukar mengkristal, fungsi utama tanin adalah sebagai antioksidan biologis [1]. Tanin merupakan senyawa metabolit sekunder yang akan cenderung bersifat polar.

Secara umum, (Cyclea Barbata Miers) mengandung karbohidrat, lemak, protein dan senyawa-senyawa lainnya seperti polifenol dan flavonoid yang mengandung aktivitas antioksidan, mineral-mineral dan vitamin-vitamin, serta serat pektin.Ekstrak bahan alam khususnya senyawa yang mengandung atom $\mathrm{N}, \mathrm{O}, \mathrm{P}, \mathrm{S}$, dan atomatom yang memiliki pasangan elektron bebas.Korosi yang terjadi pada logam tidak dapat dihindari, tetapi hanya dapat dicegah dan dikendalikan sehingga struktur atau komponen mempunyai masa pakai yang lebih lama. Kerugian yang akan dialami dengan adanya korosi meliputi finansial dan safety, diantaranya: penurunan kekuatan material, penipisan, downtime dari equipment, retak \&pitting, kebocoran fluida, embrittlement, penurunan sifat permukaan material, penurunan nilai / hasil produksi, modification [2].

\section{METODE PENELITIAN}

Penelitian ini dimulai dari pengambilan daun cincau hijausegar sebanyak 2500 gram dikeringkan di udara terbuka selama 22 hari untuk menghilangkan kadar air. Kemudian daun yang telah kering dihaluskan hingga menjadi serbuk. Dengan metode maserasi, yaitu memasukkan daun cincau hijaukering yang telah halus sebanyak 300 gram ke dalam wadah botol yang berisi etanol 2 liter.Metode maserasi dilakukan dengan merendam daun cincau hijau kering dalam pelarut selama 24 jam.Hasil perendaman kemudian disaring menggunakan kertas saring sehingga diperoleh filtrat. Filtrat kemudian diuapkan menggunakan mesin rotary evaporator dengan kecepatan 200 rpm dan suhu $50^{\circ} \mathrm{C}$ hingga menghasilkan ekstrak yang pekat.

Selanjutnya baja yang sudah dipotong dengan ukuran $10 \mathrm{~mm}$, lebar $10 \mathrm{~mm}$, dan tinggi $5 \mathrm{~mm}$ dibersihkan dengan amplas kemudian ditimbang. Setelah itu, masuk dalam tahap pembuatan medium korosif $\mathrm{NaCl}$ dengan konsentrasi 3\%.Pembuatan larutan $\mathrm{NaCl}$ dengan konsentrasi $3 \%$ yaitu 3 gram $\mathrm{NaCl}$ ditambahkan dengan aquades sampai volume $100 \mathrm{ml}$.

Setelah semuanya tercampur, maka tahap selanjutnya masuk dalam tahap perendaman. Pada tahap ini, baja yang sudah ditimbang dimasukkan dalam medium korosif $\mathrm{NaCl} 3 \%$ dengan konsentrasi inhibitor $0 \%, 2 \%, 4 \%$ dan $6 \%$ dengan perendaman variasi suhu $40{ }^{\circ} \mathrm{C}$ dan $80{ }^{\circ} \mathrm{C}$ maka, ada 8 sample pengujian. Perendaman sampel ditunjukkan pada Gambar 1. Setelah direndam, sampel ditimbang kembali untuk mengetahui pengurangan massa sesudah perendaman dengan suhu.

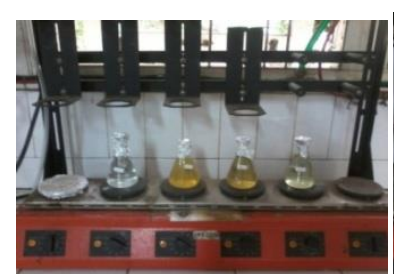

(a)

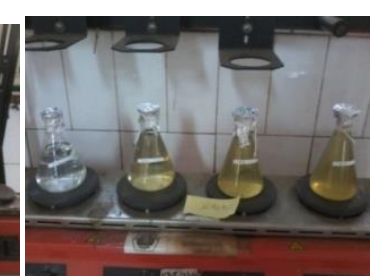

(b)
Gambar 1. Perendaman sample dengan variasi suhu (a) $40{ }^{\circ} \mathrm{C}$ dan (b) $80^{\circ} \mathrm{C}$. 
Tabel 1. Kode sampel.

\begin{tabular}{ccccc}
\hline No & Kode Sampel & Suhu $\left({ }^{\circ} \mathrm{C}\right)$ & Konsentrasi inhibitor $(\%)$ & Keterangan \\
\hline 1. & PGDaun-A & & 0 & $\begin{array}{c}\text { Sampel Baja Pegas Daun } \\
\text { murni }\end{array}$ \\
2. & PGDaun-40-0 & 40 & 0 & Dengan perlakuan \\
3. & PGDaun-40-2 & & 2 & \\
4. & PGDaun-40-4 & & 4 & \\
5. & PGDaun-40-6 & & 0 & Dengan perlakuan \\
\hline 6. & PGDaun-80-0 & & 2 & \\
7. & PGDaun-80-2 & 80 & 4 & \\
8. & PGDaun-80-4 & & 6 & \\
9. & PGDaun-80-6 & & 0 & \\
\hline
\end{tabular}

Analisis kualitatif terhadap hasil XRD dengan metode search match analysis/metode pencocokan data yang diperolehdari software yang digunakan untuk mengidentifikasi adalah HighScore Plus. Kemudian, untuk mengetahui struktur permukaan baja maka dilakukan uji SEM. Pada uji ini menggunakan detektor back scattered, elektron memberikan perbedaan berat molekul dari atom-atom yang menyusun permukaan, atom dengan berat molekul lebih besar akan berwarna lebih cerah dari pada atom dengan berat molekul rendah. Untuk memperkuat, bahwa baja yang digunakan telah terkorosi maka dilakukan uji EDS. Pengujian EDS menggunakan detector SE (Secondary electron). Perhitungan laju korosi dan efisiensi inhibitor ditunjukkan pada Persamaan 1 dan 2.

$$
C R=\frac{K W}{A T \rho}
$$

Keterangan, $C R=$ laju korosi (mm/tahun), $K=$ konstanta laju korosi, $W=$ selisih massa $(\mathrm{mg}), A=$ luas permukaan $\left(\mathrm{mm}^{2}\right)$, $T=$ waktu perendaman (tahun), $\rho=$ massa jenis $\left(\mathrm{mg} / \mathrm{mm}^{3}\right)$.

$\eta(\%)=\frac{\left(C R_{\text {uninhibited }}-C R_{\text {inhibited }}\right)}{C R_{\text {uninhibited }}} \times 100 \%$

Keterangan, $\eta=$ efisiensi inhibitor (\%), $C R_{\text {uninhibited }}=$ laju korosi tanpa inhibitor (mm/tahun), dan $C R_{\text {inhibited }}=$ laju korosi dengan inhibitor (mm/tahun) [3]. Untuk mempermudah penyajian dan analisis data maka digunakan teknik pengkodean sampel seperti ditunjukkan pada Tabel 1.

\section{HASIL DAN PEMBAHASAN}

\section{Hasil Perhitungan Laju Korosi}

Berdasarkan Gambar 2. dapat diketahui bahwa pada sampel yang ditambahkan konsentrasi ekstrak daun cincau hijau dengan konsentrasi 0 sampai 6 $\%$ mengalami perubahan penurunan massa semakin kecil. Sedangkan, pada sampel suhu $40{ }^{\circ} \mathrm{C}$ yang ditambahkan konsentrasi ekstrak daun cincau sebanyak $4 \%$ perubahan massa sampel mengalami kenaikan. Terjadinya penurunan perubahan massa menunjukkan bahwa permukaan baja tersebut terkikis oleh korosi.

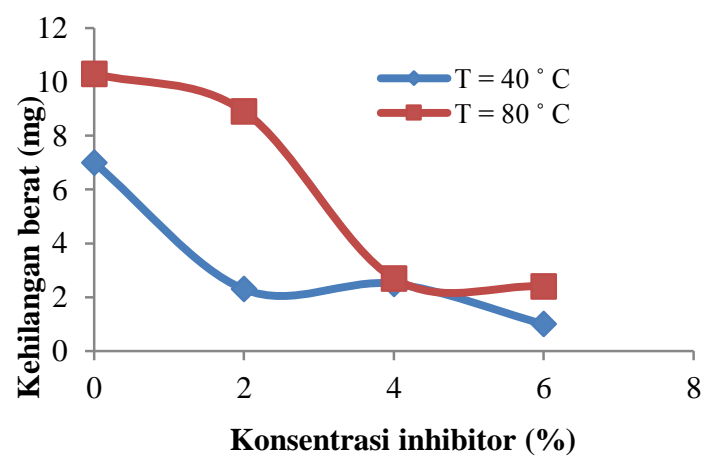

Gambar 2. Grafik hubungan kehilangan berat sampel dan konsentrasi inhibitor

Perubahan pada penurunan massa yang kecil ini diakibatkan karena adanya 
penambahan inhibitor pada medium korosif.Inhibitor daun cincau hijau ini mengandung senyawa flavonoid, alkanoid, polifenol, dan tanin yang dapat berikatan dengan logam sehingga perubahan massa akan semakin kecil[4]. Sedangkan, pada kenaikan laju korosi dikarenakan tidak homogen pada saat pembuatan medium korosif. Perubahan massa sampel yang direndam pada suhu $80{ }^{\circ} \mathrm{C}$ mengalami perubahan massa lebih besar dibandingkan saat sampel di rendam pada suhu $40^{\circ} \mathrm{C}$.

Grafik pada Gambar 2 menunjukkan grafik hubungan kehilangan berat sampel dan konsentrasi inhibitor. Pada grafik diatas terlihat kenaikan suhu pada perendaman akan menyebabkan bertambahnya kecepatan reaksi korosi. Hal ini terjadi karena semakin tinggi suhu, maka energi kinetik dari partikel-partikel yang bereaksi akan meningkat sehingga melampaui besarnya energi aktivasi dan akibatnya laju kecepatan reaksi atau korosi juga akan semakin cepat[5]. Berdasarkan hasil pengamatan yang didapatkan pada Tabel 1 setelah dilakukan perhitungan seperti ditunjukkan pada Gambar 2 maka didapatkan besar laju korosi masing-masing sampel seperti pada Tabel 2 berikut ini.

Berdasarkan Tabel 2 dapat diketahui bahwa pada suhu $40^{\circ} \mathrm{C}$ laju korosi tertinggi yaitu pada sampel tanpa inhibitor dan laju korosi terendah pada sampel dengan inhibitor $6 \%$.

Tabel 2. Laju korosi baja pegas daun dalam larutan

\begin{tabular}{ll}
\multicolumn{2}{c}{$\mathrm{NaCl} 3 \%}$. \\
\hline Kode sampel & Laju korosi (mm/y) \\
\hline PGDaun-40-0 & 333,26 \\
PGDaun-40-2 & 40,37 \\
PGDaun-40-4 & 56,73 \\
PGDaun-40-6 & 12,53 \\
\hline PGDaun-80-0 & 256,32 \\
PGDaun-80-2 & 175,59 \\
PGDaun-80-4 & 3,9684 \\
PGDaun-80-6 & 52,03 \\
\hline
\end{tabular}

Sedangkan, pada suhu $80^{\circ} \mathrm{C}$ laju korosi tertinggi yaitu terdapat pada sampel tanpa inhibitor dan laju korosi terendah yaitu terdapat pada sampel dengan inhibitor $6 \%$. Laju korosi tertinggi terjadi pada sampel tanpa inhibitor karena besi bereaksi secara mudah dengan tidak adanya penghambat sehingga korosi mudah terjadi.Kemudian, laju korosi pada baja ini mengalami penurunan ketika medium korosi telah ditambahkan inhibitor, hal ini menunjukkan bahwa inhibitor yang digunakan bekerja.

Aksi inhibitor diharapkan dapat membuat ketahanan logam terhadap korosi lebih besar. Dengan adanya penambahan inhibitor kedalam medium korosif, maka akan menyebabkan laju reaksi menjadi lebih rendah, sehingga waktu kerja inhibitor untuk melindungi logam menjadi lebih lama. Pada kemampuan inhibitor untuk melindungi logam dari korosi akan hilang atau habis pada waktu tertentu, hal itu di karenakan semakin lama waktunya maka inhibitor akan semakin habis terserang oleh larutan inhibitor. Pada ekstrak daun cincau hijau ini memiliki senyawa-senyawa organik yang memenuhi karakteristik inhibitor senyawa organik yang menjadi sarana bagi inhibitor berikatan dengan logam secara koordinasi [6]. Kemudian, perendaman suhu $80^{\circ} \mathrm{C}$ mempunyai laju korosi lebih tinggi jika dibandingkan dengan laju korosi yang terjadi pada suhu $40^{\circ} \mathrm{C}$. Hal ini sesuai dengan hasil penelitian [7] bahwa semakin tinggi suhu maka nilai laju korosinya juga semakin tinggi [7] .

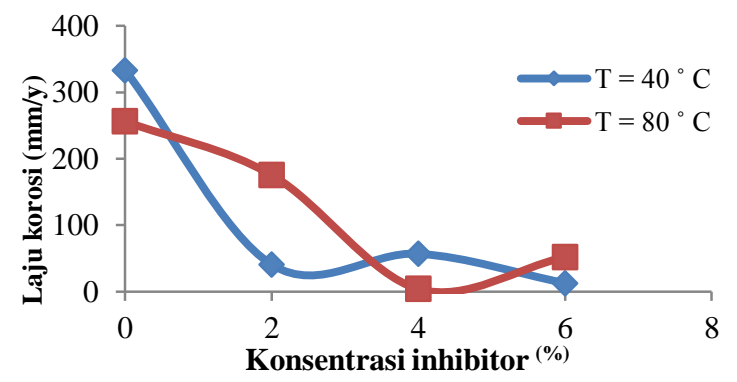

Gambar 2. Pengaruh konsentrasi inhibitor dan suhu perendaman terhadap laju korosi baja pegas daun dalam larutan $\mathrm{NaCl} 3 \%$.

Selanjutnya, diatas yaitu grafik pengaruh konsentrasi inhibitor dan suhu 
perendaman terhadap laju korosi baja pegas daun dalam larutan $\mathrm{NaCl} 3 \%$ ditunjukkan pada Gambar 2. Berdasarkan pada Gambar 2 dapat dilihat bahwa penambahan ekstrak daun cincau hijau berdasarkan konsentrasi, dapat melindungi permukaan besi sehingga mengurangi laju korosi. Penambahan pada ekstrak daun cincau hijau terjadi penurunan laju korosi pada suhu $40{ }^{\circ} \mathrm{C}$ dengan konsentrasi 2 dan 6 $\%$. Penurunan ini di karenakan adanya senyawa tanin pada ekstrak daun cincau hijau yang dapat membentuk senyawa kompleks di permukaan baja.

Senyawa kompleks ini teradsopsi pada permukaan baja yang menghalangi serangan $\mathrm{NaCl}$ sehingga laju korosi menurun [8]. Sedangkan, pada penambahan ekstrak daun cincau hijau dengan konstentrasi inhibitor $4 \%$ pada suhu $40^{\circ} \mathrm{C}$ laju korosi mengalami peningkatan.Hal ini menunjukkan bahwa semakin lama baja direndam dalam medium korosif maka laju korosi akan menurun, dengan demikian penurunan ini disebabkan waktu perendaman berpengaruh terhadap laju korosi dan penambahan terhdap inhibitor pada medium korosif[9]. Hal ini juga diakibatkan dengan adanya lapisan Fe-tanin pada ekstrak daun cincau hijau yang tidak bisa menutupi seluruh permukaan baja, sehingga bagian baja yang tidak tertutupi dapat terion dan mengalami korosi.Selain itu, kenaikan pada laju korosi ini menunjukkan bahwa inhibitor ekstrak daun cincau hijau yang digunakan telah mampu menanggulangi korosi dengan baik.

\section{Analisis XRD (X-RayDiffraction)}

Uji XRD ini digunakan untuk mengetahui fasa yang terbentuk dari baja pegas daun dengan suhu perendaman 40 ${ }^{\circ} \mathrm{C}$ dan $80{ }^{\circ} \mathrm{C}$. Hasil uji XRD ini akan menghasilkan puncak-puncak, dengan puncak yang tinggi merupakan fasa kristal, sedangkan puncak yang melebar merupakan fasa amorf. Pengujian dilakukan pada sampel PGDaun-A, PGDaun-40-0, dan PGDaun-80-0.Hal ini dilakukan karena untuk melihat pengaruh inhibitor ekstrak daun cincau hijau baik sebelum direndam dan sesudah direndam menggunakan inhibitor dan tanpa inhibitor terhadap fasa yang terbentuk.Kemudian, hasil baja yang telah diberikan perlakuan tersebut dibandingkan dengan baja murni (raw). Hasil difragtogram untuk sampel baja PGDaun-A, PGDaun-40-0, dan PGDaun-80-0 ditunjukkan pada berikut ini.

Pada Gambar 3 dapat dilihat, hasil yang didapatkan puncak-puncak tajam yang mengidentifikasi bahwa sampel terbentuk fasa kristal. Intensitas yang tinggi menunjukkan presentase unsur $\mathrm{Fe}$ juga tinggi. Karena beda intensitasnya, maka semakin tinggi puncaknya maka nilai kristalinnya juga semakin besar [10]. Pada sampel PGDaun-A, PGDaun-40-0, dan PGDaun-80-0 dapat dilihat bahwa tingkat ketinggian intensitas fasa $\mathrm{Fe}$ masingmasing sampel berbeda-beda.Hal ini menunjukkan bahwa perlakuan yang diberikan pada baja berhasil.

Kemudian pada sampel PGDaun-A (raw) terlihat bahwa intensitas puncak yang terbentuk pada sampeltanpa inhibitor dengan perendaman suhu $80^{\circ} \mathrm{C}$ lebih tinggi dibandingkan dengan sampel yang tidak melakukan perlakuan ( $r a w$ ). Selain itu, pada masing-masing sampel terdapat tiga puncak. Hal ini menunjukkan bahwa kandungan Fe pada sampel tanpa inhibitor berkurang dan inhibitor yang digunakan bekerja dan inhibitor puncak-puncak difraksi menjadi berkurang akibat penambahan inhibitor [11].

Bidang (110) mempunyai persentase keterisian atom besi paling besar yang memiliki kecenderungan terkecil tersisipi atom karbon, dimana atom karbon ini akan memberikan perlindungan terhadap pelepasan atom besi [12]. 


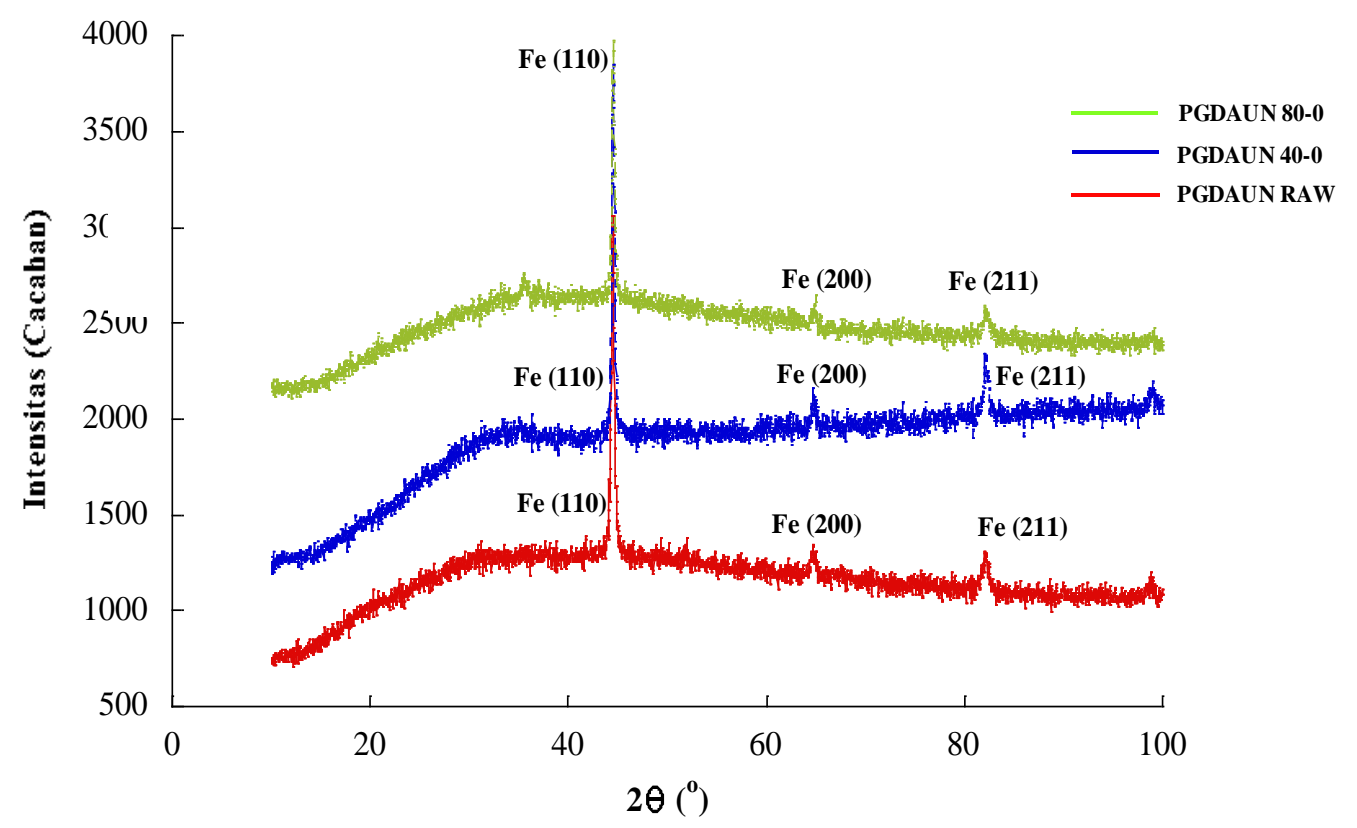

Gambar 3. Difragtogram sampel PGDaun-A, PGDaun-40-0, dan PGDaun-80-0.

Namun, pada difraktogram menunjukkan bahwa pada bidang (110) paling terlindungi dibandingkan bidang lainnya.Bidang (110) merupakan ciri khas besi atau Fe dengan menunjukkan indeks miller (110). Pada karakterisasi XRD ini pengaruhnya $\mathrm{Fe}$ setelah dilakukan perendaman yaitu untuk melihat kandungan Fe apakah puncak nya lebih besar setelah ditambahkan atau dikurangi inhibitor.

\section{Analisis SEM-EDS}

Analisis EDS bertujuan untuk mengetahui komposisi unsur atau senyawa yang terdapat pada permukaan sampel, selain analisis EDS juga dilakukananalisis SEM yang bertujuan untuk mengetahui struktur mikro pada permukaan sampel. Pada pengujian EDS menggunakan detector SE (Secondary electron) sedangkan, pengujian SEM menggunakan detektor BSE (Back-scattered Electron) ini bertujuan agar permukaan baja yang telah terkorosi terlihat dengan jelas.Pengujian SEM dilakukan dengan 4 kali perbesaran yaitu 500x, 1000x, 3000x, dan 5000x.

Gambar 4 menunjukkan hasil analisis SEM, pada gambar (a) merupakan hasil analisis pada sampel PGDaun-A dengan perbesaran 5000x, adanya lubang-lubang halus yang terlihat hal ini dikarenakan pengaruh dari pengamplasan pada sampel. Masih terlihat bahwa pada permukaan baja belum ada retakan dan juga gumpalan namun, terlihat adanya lubang pada sampel.Lubang-lubang tersebut tebentuk karena disebabkan oleh logam $\mathrm{Ni}$ yang dihasilkan saat peleburan. Logam Ni yang terdapat pada hasil peleburan berbentuk pori atau poros[13].Tujuan dilakukan SEM pada sampel PGDaun-A ini adalah sebagai acuan dan pembanding untuk sampelsampel yang telah dilakukan dengan berbagai perlakuan. 


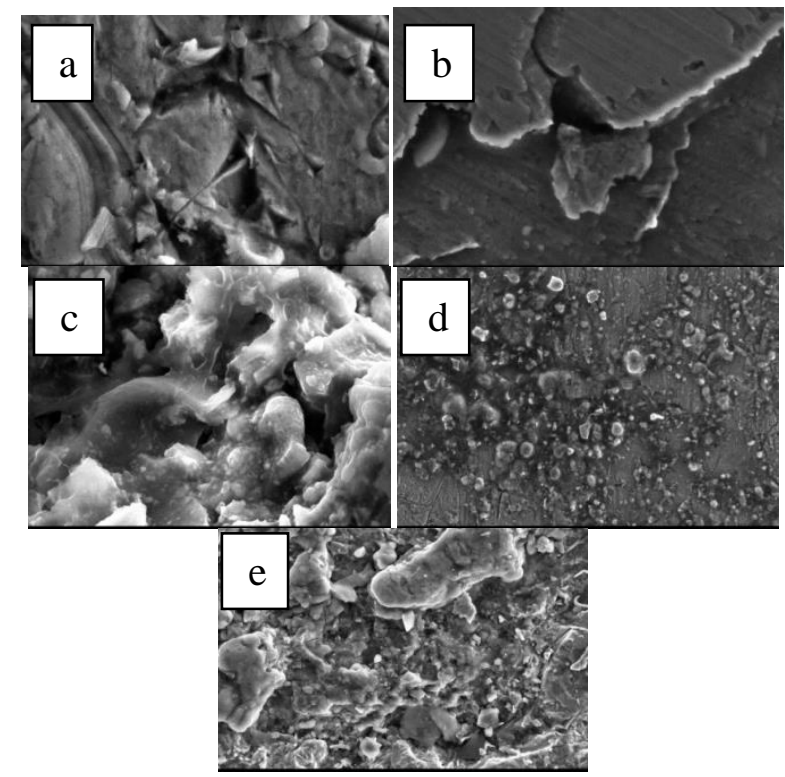

Gambar 4. Hasil SEM baja Pegas Daun (a) sampel PGDaun-A (raw) (b) perendaman suhu $40^{\circ} \mathrm{C}$ dengan tanpa inhibitor sampel PGDaun-40-0(c) sampel perendaman suhu $80^{\circ} \mathrm{C}$ dengan tanpa inhibitor sampel PGDaun-80-0 (d) perendaman suhu $40^{\circ} \mathrm{C}$ dengan tanpa inhibitor sampel PGDaun-40-2(e) perendaman suhu $80^{\circ} \mathrm{C}$ dengan tanpa inhibitor sampel PGDaun-80-6

Pada Gambar 4(b) terlihat adanya gumpalan pada permukaan baja setelah direndam dalam larutan $\mathrm{NaCl} 3 \%$ tanpa menggunakan inhibitor dengan menggunakan suhu $40^{\circ} \mathrm{C}$ dengan perbesaran 5000x. Pada gambar tersebut menunjukkan gumpalan-gumpalan merupakan produk korosi yang terbentuk. Gumpalan yang dihasilkan tidak tersebar merata pada permukaan sampel. Kemudian, pada Gambar 4(c) sampel dengan menggunakan suhu $80^{\circ} \mathrm{C}$ tanpa menggunakan inhibitor dengan perbesaran 3000x, pada gumpalangumpalan yang melebar.

Gumpalan yang dihasilkan hampir tersebar merata pada permukaan sampel dan terdapat retakan. Selain itu, terlihat retakan pada permukaan disekitar gumpalan dan hasil SEM ini diakuratkan dengan hasil perhitungan efisiensi inhibitor dimana pada sampel PGDaun-80-0 dengan perbesaran 3000x yang memiliki efisiensi yaitu sekitar 31,49\%. Selanjutnya, hasil analisis SEM untuk sampel PGDaun-40-2 ditunjukkan pada Gambar 4(d). Pada Gambar 4(d) menunjukkan pengaruh suhu terhadap korosi baja PGDaun-40-2 dengan menggunakan inhibitor 2\%.Pada Gambar 4(d) merupakan analisis sampel dengan perbesaran 500x.Pada gambar tersebut terlihat bahwa pada permukaan sampel terbentuk gumpalan-gumpalan bulat dan retakan.Pada Gambar 4(e) pada sampel dengan menggunakan suhu $80^{\circ} \mathrm{C}$ dengan konsentrasi $6 \%$ yang diperbesar 1000x terlihat lebih terkorosi atau produk-produk korosi yang terbentuk dan terlihat adanya gumpalan. Hal ini menunjukkan bahwa korosi lebih cepat terjadi pada suhu yang digunakan $80^{\circ} \mathrm{C}$. Selain itu, hal ini sesuai dengan hasil penelitian tentang pengaruh suhu yaitu dapat menjadi salah satu faktor mempercepat laju korosi.

Hasil pengujian EDS sampel PGDaunA (raw) ditunjukkan pada Gambar 5 (a). Pada sampel ini terdeteksi bahwa senyawa tertinggi yaitu $\mathrm{FeO}$ sebesar 79,00 \%, karena pada sampel ini merupakan baja raw material yang tidak diberi perlakuan sehingga kandungan unsur besi $(\mathrm{Fe})$ masih sangat tinggi. Pada Gambar 5 (b), (c), (d) dan (e) terlihat unsur $\mathrm{Fe}$ mempunyai persentase lebih rendah dibandingkan pada Gambar 5 (a). Hal ini menunjukkan bahwa sampel ini telah terkorosi. Kemunculan unsur $\mathrm{O}$ pada sampel dikarenakan sampel 
ini telah terkontaminasi dengan udara yang mengandung oksigen.

Kemudian, muncul juga unsur $\mathrm{Na}$ dan $\mathrm{Cl}$ yang dikarenakan pada saat perendaman menggunakan medium korosif $\mathrm{NaCl}$ sehingga unsur $\mathrm{Na}$ menempel pada permukaan sampel.Selain itu, juga terdeteksi unsur $\mathrm{Si}, \mathrm{Mg}$, dan $\mathrm{Al}$, hal ini dikarenakan $\mathrm{Si}, \mathrm{Mg}$, dan $\mathrm{Al}$ adalah unsur penyusun baja Pegas Daun. Produk korosi

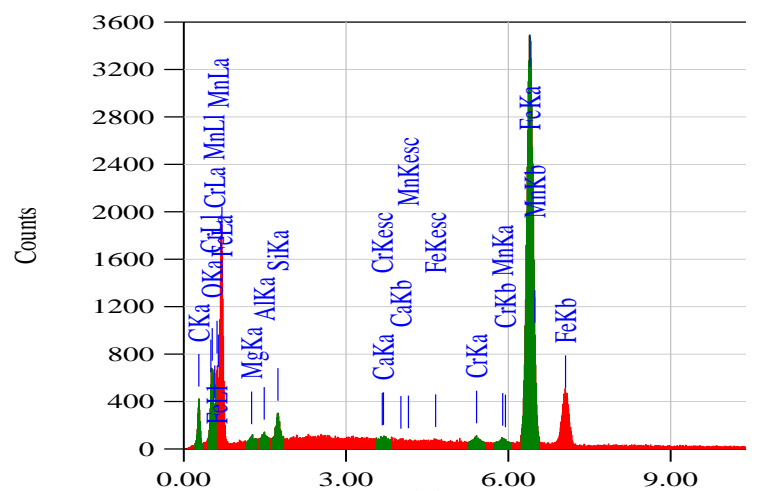

(a)

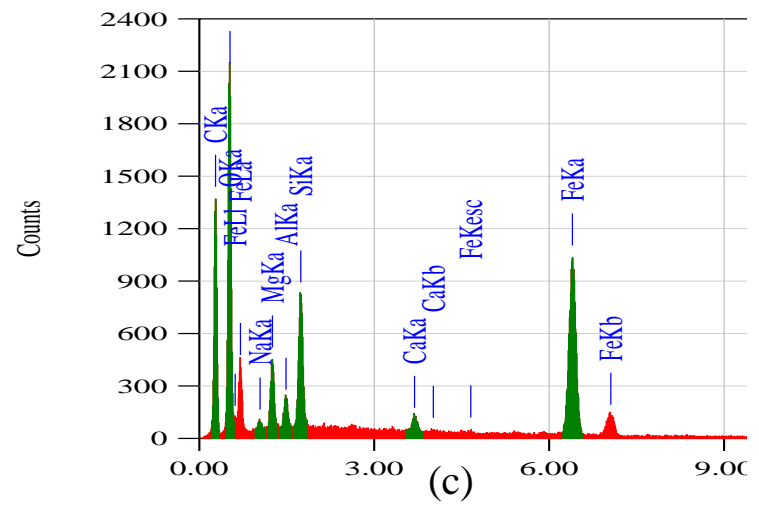

(c)

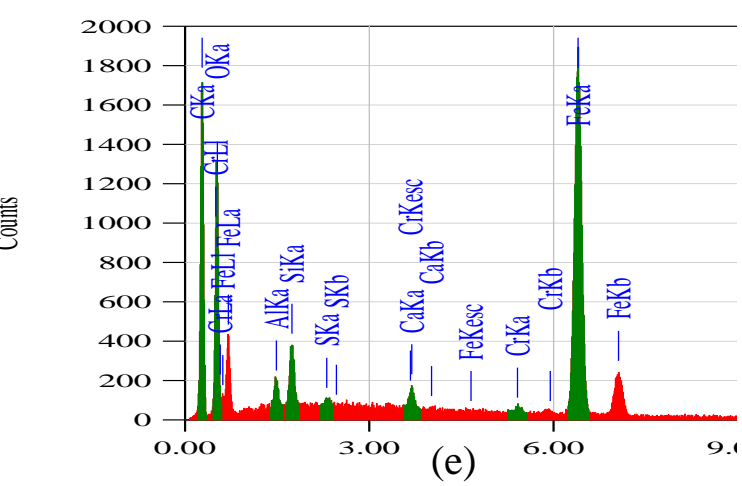

Gambar 5. Hasil EDS baja Pegas Daun (a) sampel PGDaun-A (raw) (b) perendaman suhu $40^{\circ} \mathrm{C}$ dengan tanpa inhibitor sampel PGDaun-40-0(c) sampel perendaman suhu $80^{\circ} \mathrm{C}$ dengan tanpa inhibitor sampel PGDaun-80-0 (d) perendaman suhu $40^{\circ} \mathrm{C}$ dengan tanpa inhibitor sampel PGDaun-40-2 (e) perendaman suhu $80^{\circ} \mathrm{C}$ dengan tanpa inhibitor sampel PGDaun-80-6.
(Fe) pada sampel PGDaun-40-0 lebih tinggi dibandingkan produk korosi pada sampel PGDaun-40-2, hal ini mengindikasikan bahwa inhibitor bekerja. Kemudian, persentase Fe pada sampel PGDaun-80-6 lebih tinggi dibandingkan PGDaun-80-0 persentase Fe pada sampel, hal ini berarti suhu tinggi mempercepat laju korosi. Hasil EDS ini memperkuat hasil XRD.

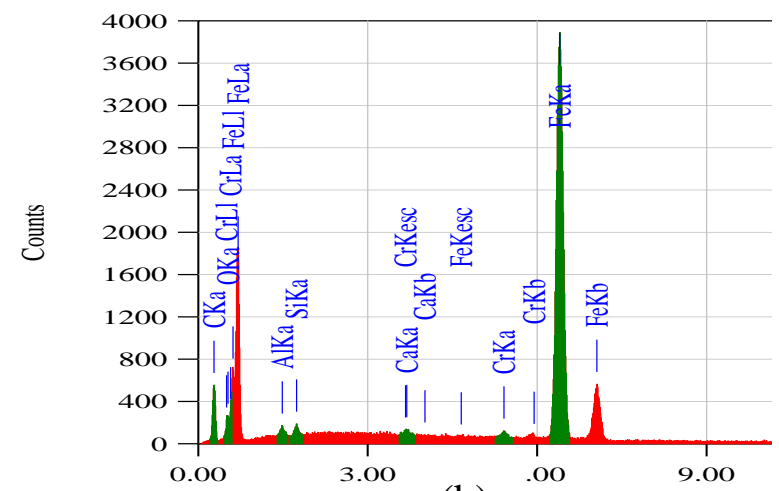

(b)

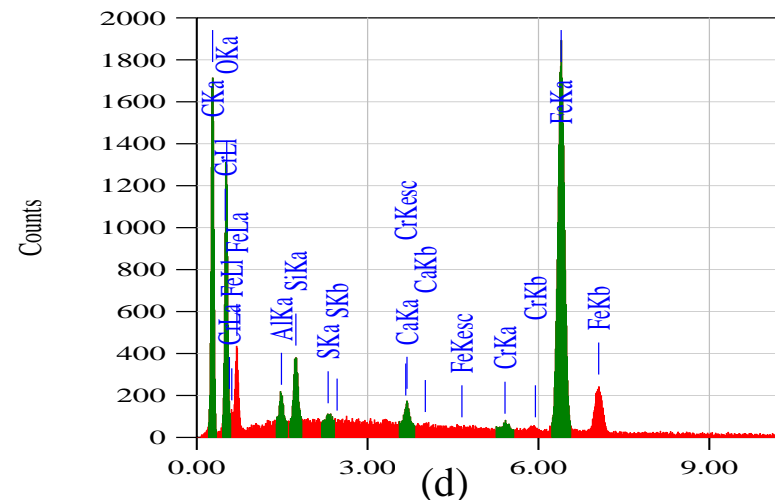

(d) 


\section{KESIMPULAN}

Semakin bertambahnya konsentrasi maka laju korosinya semakin menurun dan semakin lama waktu perendaman maka laju korosi yang dihasilkan akan semakin menurun.Efisiensi tertinggi terdapat pada konsentrasi $6 \%$ dengan suhu perendaman $40{ }^{\circ} \mathrm{C}$ yaitu sebesar 96,24\%. Dari ketiga hasil analisis dan perhitungan laju korosi didapatkan bahwa inhibitor ekstrak daun cincau hijau(Cyclea Barbata Miers) efektif dalam menginhibisi laju korosi pada baja Pegas Daun.Berdasarkan hasil analisis SEM permukaan sampel PGDaun-40-2 lebih terkorosi lebih terkorosi dibandingkan permukaan sampel PGDaun-40-0 lebih terkorosi.Begitu juga sampel PGDaun-80-6 lebih terkorosi dari sampel PGDaun-80-0.

\section{UCAPAN TERIMA KASIH}

Penulis mengucapkan terimakasih kepada kepala Laboratorium Fisika DasarUniversitas Lampung, Laboratorium Kimia Organik FMIPA Universitas Lampung, untuk fasilitas Laboratorium.

\section{DAFTAR PUSTAKA}

[1] F. Ariyani, N. S. Saputri, and L. Nurhidayati, "Efektivitas Daun Cincau Hijau (Cyclea barbata Miers) Sebagai Antioksidan Alami Pada Produk Jambal Patin (Pangasius hypopthalmus)," Pascapanen dan Bioteknologi Kelautan dan Perikanan, vol. 4, no. 2. pp. 169-175, 2009.

[2] B. Utomo, "Jenis korosi dan penanggulangannya," Jenis Korosi dan Penanggulangannya, vol. 6, no. 2, pp. 138-141, 2009.

[3] F. Khoiriatun and P. Yatiman, "APPLICATION OF THIOUREA AS CORROSION INHIBITOR FOR
SOLUTION AT $30 \square$ C," Fis. Terap., vol. 6, pp. 1-10, 2017.

[4] J. Kimia, F. Matematika, P. Alam, and U. Bengkulu, "Penghambatan Reaksi Korosi Baja Dengan Menggunakan Ekstrak Kulit Buah Manggis ( Garcinia Mangostana L ) Sebagai Inhibitor Dalam Larutan Garam," Fis. Terap., vol. 4, no. 1, pp. 273-276, 2007.

[5] S. Marlina S. Pakpahan, Ediman Ginting, "Inhibisi Korosi Baja Karbon Rendah C-Mn Steel Oleh Ekstrak Daun Teh (Camellia Sinensis) Dalam Medium Korosif," vol. 03, no. 02, pp. 195-201, 2015.

[6] H. A. Melati, Fitrilawati, R. Hidayat, W. Suratno, and N. Syakir, "Corrosion Protection on Carbon Steel of Oil and Gas Distribution Pipeline in Saline Environment Using Hybrid Polymers Based on Glymo Monomers," Bionatura, vol. 13, no. 1, pp. 1-7, 2011.

[7] F. H. Haryono, G., SUGIARTO., “( ) 2 - ( ) 2," KOROSI, vol. 1, no. 1, pp. $1-6,2010$.

[8] M. I. Noor, E. Yufita, J. Fisika, and F. Matematika, "Identifikasi Kandungan Ekstrak Kulit Buah Naga Merah Menggunakan Fourier Transform Infrared ( FTIR ) dan Fitokimia Identification Content of the Red Dragon Fruit Extract Skin Using Fourier Transform Infrared ( FTIR ) and Phytochemistry," J. Aceh Phys. Soc., vol. 5, no. 1, pp. 14-16, 2016.

[9] K. J. Pattireuw, F. A. Rauf, R. Lumintang, T. Mesin, U. Sam, and R. Manado, "Analisis Laju Korosi Pada Baja Karbon Dengan Menggunakan Air Laut Dan H 2 So 4," Univ. Sam 
Ratulangi Manad., vol. 4, pp. 1-3, 2013.

[10] P. Ahvenainen, "Comparison of sample crystallinity determination methods by X-ray diffraction for challenging cellulose I materials Comparison of sample crystallinity determination methods by $\mathrm{X}$-ray diffraction for challenging cellulose I materials," vol. 23 , no. 2 , pp. $1073-$ 1086, 2016.
[11] G. Priyotomo, Free e-book edisi mahasiswa, vol 1,no1, januari 2008 1, vol. 1. 2008, 2008.

[12] M. S. Setiawan, I. Nur, "Meningkatkan Mutu Baja Sup 9 Pada Pegas Daun Dengan Proses Perlakuan Panas," Fis. Terap., vol. 9, pp. 36-44, 2008.

[13] Soekirman, "Universitas sumatera utara," Univ. Sumatera Utara, no. X, pp. 1-5, 2014. 